\author{
Attila K. Molnár
}

\title{
Thomas Molnar and the Conservatives in the US
}

\section{SUMMARY}

Thomas Molnar, a Hungarian Catholic emigé, was a well known fugure in the American conservative movement. In spite of the warm welcome of his works criticizing leftism, he stayed at the margin of this movement. Molnar never accepted the fusionism, he was critical concerning free market, and he openly refused many presuppositions of the Anglo-Saxon liberal democracy. He transported elements of the French Catholic conservative thinking into the US like the attraction to monarchical authority and hierarchy. For him the idea of time-tested tradition was hardly important, when he used the notion of tradition he referd to its perennialist meaning. The paper argues that his criticism of (political) modernity was form by the Pascendi dominici gregis.

Keywords: Thomas Molnar, Catholicism, conservative, egalitarianism, authority

In the period of transformation of Hungary during the early 90 s, the term "conservative" had rather bad connotations.
On the one hand, it meant hard-line communists who insisted on the party state, and on the other hand, it meant old or strange people behind the times, having outdated and anachronistic ideas. History and the final success were thought to be obviously on the side of progressives, who, by means of their extraordinary talents and moral insight, could understand the necessity of historical changes and progress.

The use of this attribute in a positive sense was started by a few people around the governing Centre-Right party in 1991-1992, but in those days no politician or media self-identified as conservative in Hungary. The monopoly of triumphant liberalism - as even the post-communist party used liberal rhetoric - was slowly broken, and in this process Thomas Molnar had an important role.

Up to now, those who contradict liberal hegemony have been labelled by them as radicals or populists, if not worse, but never as conservatives, because this attribute was gradually assigned an increasingly positive connotation in Hungary

Attila K. Molnar, historian ideas, director of the Thomas Molnar Institute for Advanced Studies, National University of Public Service (attilakarolymolnar@ gmail.com). 
during the two decades after 1990. This brand was so much transvalued that there has emerged a debate around its ownership. As many decades before in the US, in Hungary the positive rebranding of the term conservative was followed by the emergence of the term pseudo-conservative used by leftist and liberals to devaluate their opponents.

Thomas Molnar, an American emigré, had a non-negligible role in the revaluation of the term 'conservative' in Hungary. After 1990 he returned to Hungary from the US, and then every year he spent several months in Hungary.

Although he was an American citizen and a respected member of the conservative circles there, he did not belong to the mainstream in the US. He always stayed away from fusionism, he was always European, too much European.

The history of the American conservatives - against from the story told by progressives - is not the fight between of the elite defending its privileges and the people, and the contemporary Hungarian situation was similar. Here, just like in the US, the conservatives were not established at all - in the US there has been a liberal hegemony, while in Hungary a communist dictatorship and after 1989 a liberal hegemony, too -, moreover in both places the conservatives challenged the established and hegemonic progressive elite. Maybe, the belligerent or critical tone of conservatives in both countries is originated from this situation. Because in the 20th century the progressive established themselves and they have became the political, economic, media and cultural elite, they formed a new rhetoric against conservatives. Not their alleged selfish defence of privileges and interests has been the main accusation against conservatives, but the triumphant progressives have emphasized that only they recognized the progress. That is why they had been successful, and the conservatives had been hopelessly behind the time. According to the progressivist self-image, because of their special knowledge of the iron laws of historical progress, only they could recognize the dictates of progress and adapt themselves to them, therefore the conservatives have been necessarily losers. Conservatives failed the moral and epistemological challenge of modernity. It has been a clearly social-Darwinist argument: adapt or perish. And, in case of conservatives, they did not feel any moral imperative to help the less successful people and express compassion towards marginalized groups of conservatives people.

The definition of conservative thinking has been the subject of debate. Conservative politics, and mainly its Anglo-Saxon version, seems to be fairly successful, a real alternative to progressives. What is more, progressivism seems to be out of fashion today.

An important issue within the debate on the definition of conservatives refers to its ideological or non-ideological character (Huntington, 1957). Conservatives typically refuse the label of ideology. The other important issue of this definition debate is connected loosely to the first one. This second debate is between those who define conservative thinking in terms of time (speed and time-testedness) and the problem of change (its modesty or slowness) and those who define conservative thinking by substantive elements. Obviously, the last one is closer to the rationalism or the creation of an 
ideology (Wilson, 1941; Holmes, 1993). One can find all of these interpretations among American conservatives, but the mainstream formed during the 1950s was fairly ideological and emphasized substantive elements, principles or beliefs (Kirk, 1993; 2018).

To indicate Thomas Molnar's place in the conservative topography, it is enough to mention only three main elements of American Conservative thinking:

1. The defence of a free market economy against the New Deal economy and the interventionism of a welfare state (Lloyd and Davenport, 2013). The reaction against the welfare state formed libertarian thinking in which Southern anti-federalist tradition merged with the teachings of the Austrian School (Hayek, Mises) (Miles, 1980; Tate, 2005). They criticized the welfare state in the name of freedom - mainly in the name of economic freedom, and economic effectivity and growth. Against the Democrats, emphasizing social equality and welfarism, the Republican Party has become the party of free market and economic growth.

This pro-market argument has been based on rationalist anthropology saying that every individual rationally calculates his costs and benefits apart from any communal ties or cultural bias. On a free market, containing these kinds of individuals, spontaneously there will emerge an order and a flourishing economy.

The conservatives picked the idea of free market partly because it seemed to relieve the state and solve the government problems of the 1970s: they hoped that the frustration emerging from unequal distribution of goods probably would not turn against the state and political order if it resulted from the blind operation of a market, and not from the redistributive policy of state. And they also hoped that the flourishing economy, produced by the free market, would temper social frustration.

2. As it is well known, the other branch of the American conservative thinking is from Russell Kirk's, Burkean traditionalism. This way of thinking argued against rationalism and egalitarianism and instead on behalf of the authority, tradition and values of the Anglo-Catholic thinking. They have stood up against moderns and progressives - liberals or leftists - and have started the Kulturkampf. This social or moral conservative argument has stated that modernity has been unsustainable and barbaric. Their critical stance towards a welfare stance joined with the free market criticism of welfarism.

This moral or social conservative argument, rooted in the European tradition and emerging during the 1950s in the US, was so strange in the American context that even the Republican candidate, Barry Goldwater, named their ideas "so bizarre, so archaic, so self-confounding, so remote from the basic American consensus" (quoted Brinkley, 1994, p. 411). Because of the existing liberal consent, the conservatives were called neo or radical Right, or pseudo-conservative, implying that the real conservative would defend the liberal consensus and establishment (Higham, 1959).

The first generation conservatives were taken as strange, mad ('kooks', 'crackpots'), without any chance for effective political action (Hofstadter, 1948). As Trilling put famously: "conservative impulse and the reactionary impulse do not, with some isolated and some ecclesiastical exceptions, express themselves 
in ideas but only in action or in irritable mental gestures which seek to resemble ideas" (Trilling, 1950, p. ix).

But the public mind in the US turned Right after 1968 - which was a kind of 1789 or 1793 year for many Americans (Brennan, 1995). After then, Meyer's (Meyer, 1960) fusionism has become the mainstream among the American Conservatives (Meyer, 1962; Nisbet, 1980; Goldwater, 2010; Smant, 2002; Hart, 2005; Lee, 2014; Allitt, 2009; Dunn and Woodard, 1996; Preece, 1980; Schoenwald, 2001).

3. In the original version of fusionism, the third element was not present. It is the grandeur. This element was connected to anti-communism for many years, a bond of several conservative branches (Haddigan, 2010). However, after the collapse of the Soviet Union this bond disappeared, and the emphasis on national interests gained importance (Dorrien, 2004; Kagan, 2002).

Fusionism could survive the incoherence of Kirkian traditionalism, social conservatism and libertarianism and freemarketism, but fusionism was broken by the unusual democracy export of the Republicans, which generated the conflict between paleo- and neo-conservatives.

Though it was not called fusionism then, this package appeared in Hungary after 1990 . In the period of the first free, Antall government of 1990-1993, the centre Right followed a free market policy combined with the emphasis on national sovereignty and the defence of traditional culture and religions. And this Hungarian combination of freemarketers, social or moral conservatives and nationalists worked at least for one and a half decades. (The first Orban-gov- ernment between 1998-2002 followed this combination, more or less.) But in this country this combination was not as sound as in the US. Partly, because everyone - even the post-socialists - was using the free market rhetoric and policy, so it was not a real political marker for the Right. Also, because the free market rhetoric was used for unscrupulous privatization and the creation of the crony capitalism of post-socialist technocracy. And under the flag of a free market the foreigners could gain an unusual influence on economic life after the collapse of the socialist economy. Beside the moral criticism following the corruptions of privatization and the market economy, it was crucial that the elite that were managing the free market couldn't build an effective and prosperous Hungary. As it is well known, beside the freedom argument, the most important argument for the free market was its effectiveness vis-àvis a planned economy. Hungary, under the leadership of the post-socialist elite, using free market rhetoric, descended into high unemployment, indebtedness and economic crisis. Thus, because of practical and political reasons, the Right broke with the local version of fusionism, and the ideas of the free market have got out from the thinking of Right of Hungary.

In Hungary conservative thinking divorced from free marketism in the first decades of the 21st century. Here the traditional suspicion concerning the free market has become rather widespread: conservatives suspect that the market relations transform or destroy the family, nation, traditions and religion, as it was described by Daniel Bell (Bell, 1976) or Marx. ${ }^{1}$ In spite of this suspicion and the 
obvious incoherence of the values of free market and moral or social conservative values, still there are some thin bonds between conservatives and free marketers like anti-egalitarianism, anti-communism, meritocratism and patriotism.

Obviously, Hungarian-born Thomas Molnar stood out of the fusionist mainstream. There is no reference in any of his works to the Austrian School or libertarians. In general, the criticism of the welfare state in the name of freedom and/or economic efficiency was distant from him. And, he was similarly critical towards the export of democracy. He was, probably, too European or too much of a Francophile. European, mainly continental, conservative thinking, differs clearly from the American one: the first difference is characterized by the Roman unity of tradition, authority (hierarchy of men) and religion based on the Tomist tradition. These are fused into the concept of a sacred monarchy like the divine imperators in Rome, the rex Christianissimus kings of France and the godly princes in the Protestant countries (Arendt, 1990, p. 117). The European conservative tradition insisted on the idea of the natural inequality of men and on the idea of the incompleteness of man: because man is incomplete, he needs some completion from without, like from magistrates, culture or other institutions independent from an individual's will. The conservatives in the US were much closer to the liberal anthropology: they were ready to except the ideas of equality and individualism as well as the consent of the governed as the only acceptable basis of political order.

Vis-á-vis the Anglo-Saxon conservatives, tradition interpreted in terms of time - speed of change like modesty and durability - was not interesting for continental conservatives. Continental conservatives interpreted tradition as something perennial, originating from the nature of man, and at the same time they were more critical by condemning the political, cultural or other forms of modernity than the Anglo-Saxons were. This rather solid anti-modernism was logically connected to the perennialist understanding of tradition. As in the case of Thomas Molnar, one can hardly find any concession to modernity among continental conservatives. Thomas Molnar's work can be understood mainly in terms encyclics of Syllabus Errorum (1864) and Pascendi dominici gregis (1907).

Thomas Molnar referred to de Maistre, Donoso Cortes, Voegelin and Carl Schmitt, but his thinking stood closest to Bernanos and the French circle of Charles Maurras (Molnar, 2011; 1995b) The idea of tradition as something time-tested and that survived the trial-and-error experiments, so important for Anglo-Saxons, was much less important for Molnar than the idea of authority and the idea of perennial tradition. The backbone of his thinking was God and authority, and their relation. In general, the authority became a marker for anti-modernist conservatives, probably because the modernist was not able to domesticate this idea, while the Anglo-Saxon notion of tradition was absorbed by many modernists.

According to Molnar, modernity is a hopeless, lost cause by origin because it is the fruit of the rebel: modernity is a shift from the transcendental interpretation of the world towards an immanent one. This rebel hopes that the world is self-sufficient, it can be made perfect, therefore 
it doesn't need God, nor Revelation, nor its teacher, the Church. Molnar, like his continental exemplars, always criticized the liberalismus triumphans as responsible for modernity.

The modernists' rebel means for him that modernists refuse the notion of incomplete man and that he needs some completion from without. Some kind of forum externum. Accordingly, politics is not a separate sphere or a second order activity, but the most intensive appearance of the problem of basic human relations, as Carl Schmitt wrote in his The Concept of Political (Schmitt, 1996). Therefore, the sharpest consequence of human nature is authority. Politics is not a sphere beside many others, but it is itself the problem of human relations, and their institutional solutions is the established authority. This thinking on the parallel of politics and theology haphazardly follows St Augustine's description of civitas Dei: without grace the sinful man loves himself, therefore he rebels and seeks power, so he desperately needs an authority, a forum externum to make human life possible. The (sinful) nature of man requires his subordination to some scheme or principle of order not, in its essence, made by himself.

Hobbes' question, according to Carl Schmitt (Schmitt, 2008) - Quis iudicabit? Quis interpretabitur? - refers to the epistemological side of the human condition: instead of methodology, a political decision may decide the epistemological ambiguities, such as what is reality or what is the meaning and what is the motivation of a certain action? Because of the imperfection and inscrutability of conditio humana (motives, consequences are obscure and contingent), there is need for compulsion to make order from plurality and ambiguity. Therefore, the monarchy is the core structure of the world.

In Molnar's implicit political theology, human life is founded on metaphysical presuppositions and not on conventions or experiences. By means of these ideas he questioned the liberal or modernist contractarian thinking characterizing the Americans who founded the state on individual autonomy and the consent of people. Obviously, in the thinking based on the idea of original sin, there is no practical place for the will of people.

The modernists - that is, the heretics according to Pascendi dominici gregis would solve Leo Strauss' problem ${ }^{2}$ by bracketing it. According to Molnar, this is the source of tensions in modernity. The modernists would eliminate theology and politics by utopism, because they seek to liquidate enforcement and obedience by their metaphysical turn, called humanism (Molnar, 1978). Molnar's interpretations of politics and theology are critical towards modernity because modernity basically refuses the incompleteness of man and its concomitant results, the need for hierarchical relations and institutions. Meanwhile, mainstream conservatives in the US have accepted modernity and egalitarianism.

The core idea of Thomas Molnar's works is that man, on the one hand, is zoon politikon and, on the other hand, open for transcendence, as well, and the tension between these two spheres is characteristic of the human condition. That is why man is anxious (Molnar, 1978) and looks for certainty, which is the source of his utopical propensity, that is, his search for this-worldly salvation from his anxieties. This utopism dominates modernity as 
the "synthesis of all heresies" (Pope Pius $\mathrm{X}, 1907$ ). Not the double nature of man, but rebellion against his nature was seen by Molnar as the source of problems in modernity. In this sense, modernity is not modern at all, it is only a new version of human rebellion; what is new in modernity is the triumph of heresy: "Were one to attempt the task of collecting together all the errors that have been broached against the faith and to concentrate the sap and substance of them all into one, he could not better succeed than the Modernists have done. Nay, they have done more than this, for, as we have already intimated, their system means the destruction not of the Catholic religion alone but of all religion. With good reason do the rationalists applaud them, for the most sincere and the frankest among the rationalists warmly welcome the modernists as their most valuable allies" (Pope Pius X, 1907).

The meaning of the modernists' rebel is the hope that man can get on his own, that is, he is able to become, god and self-completed (Molnar, 1987).

Original sin - in this thinking - necessitates political and ecclesiastical authority. The status naturalis is the status civilis. Any anti-political or utopical hope is against (sinful) human nature that needs authority - that is - some control from without. The social life needs the limitation of human passions, ambitions and wishes and not their liberation. Man is not rationally, nor morally autonomous. Thomas Molnar quoted Bonhoeffer to criticize the modernists' optimism that evil was declining in the world and man's power to make good had increased (Molnar, 1978).

With this thinking the ordo rerum humanorum ant the corpus politicum mysticum are always coincided. Man needs a hierarchy where authority limits his judgements and restrains his will. That is, order comes from inequality and enforcement. To get rid of them and live a decent human life at the same time is impossible - which was called "utopia" by Molnar. Only angels and animals can live peacefully without some inequalities, whereas human being needs authority (Molnar, 1995a).

The conservatives on the Continent have only moderately trusted in education or any methods on the modification of consciousness, called enlightening or consciousness raising, because the human order, first of all, is not a problem of knowledge as modernists since the Enlightenment have supposed. Modernity is full of epistemological debates about how to get the proper knowledge and what the proper knowledge is, but Molnar was pre-modern in this context. He couldn't see the moral and political problems in terms of epistemology, because these are anthropological and metaphysical ones.

For him the problem of the authority of state and church was eminently the problem of modernity. Both of these institutions are necessarily authoritative, and both are equally important to save order.

Neither conservatives nor Thomas Molnar wanted an uncontrolled or unlimited state, because politicians are fallible, too. But the control of the state by citizens - or any kind of contractarianism - wouldn't solve the problem, according to Molnar. Molnar, just as non-American conservatives generally, regularly criticized contractarian thinking and the newleft ideal of civil society, because in this thinking everyone joins to a contract by his own judgement to fulfil his wants and 
interests. Contractual relations are created to be instruments to get something. Therefore, it is easy to step in or out from them. The problem for Molnar was that an instrumental relation would never have compelling authority. As de Maistre said, man doesn't respect what was created by him and can be easily changed. Duties and loyalties connected to contractarian relations can be easily denounced. Therefore authority, in the proper sense, limiting and disciplining people for the sake of order, cannot emerge from a contract. What is more, any contractual arguments contain an anarchistic notion of freedom as something originated from the pre-social or pre-political condition. Therefore anyone may step out from these relationships. Any state founded on the notion of a contract will be in a state of permanent rebellion and resistance, because everyone wants to change the contract as a useless instrument. Modern people tend to modify their relations instead of restraining themselves. Continental conservative logic is simple: authority cannot depend on those people's permanent consent who should be disciplined by this authority. With any relation founded on personal consent, it is easy to quit the relation in case of any unwanted discipline or limitation.

If the state would be controlled directly by citizens, it would end the disciplining functioning of a state, which is necessary because of human nature. So, the control of a state is understood differently by continental conservatives: on the one hand, they suppose a transcendental world and its institutional embodiment, the Catholic Church and the pope (see Joseph de Maistre), as a reality existing above the state (Lovejoy, 2001; Mol- nar, 1988; Maistre, 1994). While liberals would limit the state by unlimited personal interests and wishes, Thomas Molnar would limit the state as well as its citizens. The presupposition of a reality above politics means also that there is something more important than politics, and a lot of issues cannot be solved by politics. Politics are not able to provide salvation in this world. The transcendental or sacred world - mediated by church, priests and rites - is the source of authority, and only this authority can integrate with the human world by disciplining people and by evoking obedience and loyalty from them. These effects of authority are connected to the same effects of morality which limits authority and is defended by authority.

Thomas Molnar found the sociological description of the sacred in Weber's notion of charisma - which in his last paper, Politics as Vocation (Weber, 2004) was not only on ideal type of legitimate order, but tacitly characterized any politician and is what put the mysticum back into its place (Molnar, 1988). ${ }^{3}$ The notion of the sacred assimilated charisma and the Burkean notion of the sublime, but Molnar took this notion mainly from Rudolf Otto's notion of mysterium tremendum et fascinans. For Molnar, power is sacred: it frightens and excites at the same time (Molnar, 1988).

The two institutions of power are the church and state - like in case of Weber. Without the sacred and these - by definition authoritative - institutions, the existence of a human order is questionable, which is necessarily a religious community (universitas fidelium) in the Gallican tradition. At this point Thomas Molnar was rather selective: he referred positively to 
Fustel de Coulanges, while refusing those French modernists who belonged to the same tradition like Rousseau, Comte and Durkheim. He explained the decline of the state and church by the ascent of "molecules", that is, the individual's conscience had become the source of the sacred (Molnar, 1988). Molnar argued that the essence of modernity/heresy/utopianism was the idea of the self-sufficient man (ens completum).

Thomas Molnar was especially interested in the Catholic Church, and beside modernists he criticized modern Catholics, too, following Pius X: "the partisans of error are to be sought not only among the Church's open enemies; they lie hid, a thing to be deeply deplored and feared, in her very bosom and heart, and are the more mischievous, the less conspicuously they appear. We allude, Venerable Brethren, to many who belong to the Catholic laity, nay, and this is far more lamentable, to the ranks of the priesthood itself, who, feigning a love for the Church, lacking the firm protection of philosophy and theology, nay more, thoroughly imbued with the poisonous doctrines taught by the enemies of the Church, and lost to all sense of modesty, vaunt themselves as reformers of the Church; and, forming more boldly into line of attack, assail all that is most sacred in the work of Christ, not sparing even the person of the Divine Redeemer, whom, with sacrilegious daring, they reduce to a simple, mere man" (Pope Pius X, 1907).

Practically, this is the core idea of his Christian Humanism: A Critique of the Secular City and Its Ideology (Molnar, 1978): The Catholic Church is threatened by the danger of becoming in its visible form a different church.
The crisis of modernity originates, according to Molnar, in the takeover of society. Instead of the sacred, (civil) society would control political and ecclesiastical power. Metaphysically, modernity is a new version of human rebellion, and sociologically, modernity is the rebel of (civil) society. Therefore, modern problems are coming from this rebellion. In this respect, he continued the criticism of revolutions and capitalism in the 19th century and the criticism of mass society in the 20th century.

The two institutions of authority are connected to the sacred, but (civil) society is not, therefore the last one cannot be the source of order, it cannot invoke tremendum and admiratio. For him, (civil) society is connected to plurality and self-interest, but pluralism gives birth to relativism and self-interests produce immanentism - i.e. there exist only thisworldly and individual realities (Molnar, 1988) - which characterizes modernity in the Pascendi dominici gregis. Society is not able to create order because of its contractual and permanently bargaining nature. (This social criticism of society was connected in his case to the moral criticism of hedonism and eudaimonism.) In modernity what are called state and church are not state and church in the proper sense, because they are curtailed from authority and sanctity. Modernity is the world of society.

There were and there will always be some frustrations in this-worldy life, there is no return to the trouble-free Paradise from the condition humana, even if man aspires to it. Those who think politics, authority and inequality are permanently necessary for a decent life usually accept this troublesome characteristic of human 
life, as well. And they, like Thomas Molnar, instead of hoping for a trouble-free world, accept that frustrations and conflicts are perennial, and authority has to exist because it is the only chance for a decent, less-than-perfect life.

„In like manner, the other pains and hardships of life will have no end or cessation on earth; for the consequences of sin are bitter and hard to bear, and they must accompany man so long as life lasts. To suffer and to endure, therefore, is the lot of humanity; let them strive as they may, no strength and no artifice will ever succeed in banishing from human life the ills and troubles which beset it. If any there are who pretend differently - who hold out to a hard-pressed people the boon of freedom from pain and trouble, an undisturbed repose, and constant enjoyment - they delude the people and impose upon them, and their lying promises will only one day bring forth evils worse than the present. Nothing is more useful than to look upon the world as it really is, and at the same time to seek elsewhere, as We have said, for the solace to its troubles" (Pope Pius X, 1907).

But in modern politics, ambitious leaders can get support from the mobilization of people by promising frustrationand a conflict-free world. In modernist thinking, governing is crisis management founded on proper knowledge - the newest and newest waves of modernists think that existence, constructed by the previous versions of modernism, is unbearable - and are not capable of making decisions. In their mind being governed means being lead to utopia, and may go together with hard frustrations and troubles which should be taken to get to utopia. The progressives want to emerge with a much better world, while the conservatives are satisfied by running a decent or liveable one. What is desirable is not necessarily possible, and the action following logical arguments does not necessarily result in the desired results. For the modernist the future is not ambiguous, but it is simply the question of real knowledge (science, expertise) and benevolent decision.

As it can be seen, Thomas Molnar separated from the American mainstream not only by his aversion to the free market and libertarianism, but more fundamentally, by his open refusal to many elements of American conservative thinking coming from a liberal heritage. From these antithetical ideas the most important ones are equality, authority, hierarchy and the sacred. He imported Continental - dominantly French Catholic - conservative ideas into the US, but these stayed isolated in the conservative coterie.

\section{Notes}

1 „All fixed, fast-frozen relations, with their train of ancient and venerable prejudices and opinions, are swept away, all new-formed ones become antiquated before they can ossify. All that is solid melts into air, all that is holy is profaned." (Marx and Engels, 1969)

2 The fundamental political and moral problem according to Strauss is: „whether men can acquire knowledge of the good without which they cannot guide their lives individually or collectively by the unaided effort of their natural powers, or whether they are dependent for that knowledge on Divine Revelation. No alternative is more fundamental than this: human guidance or divine guidance". (Strauss, 1953, p. 74) See Meier, 2006.

3 However, he was rather ambivalent concerning the concept of charismatic domination. See Molnar 1995a. 


\section{REFERENCES}

Allitt, P. (2009): The Conservatives. Ideas and Personalities throughout American History, Yale University Press, New Haven.

Arendt, H. (1990): On Revolution. Penguin Books.

Bell, D. (1976): Cultural Contradictions of Capitalism. Basic Books, New York.

Brennan, M. C. (1995): Turning Right in the Sixties. The Conservative Capture of the GOP. Chapel Hill, University of North Carolina Press.

Brinkley, A. (1994): The Problem of American Conservatism. The American Historial Review, Vol. 99, No. 2, pp. 409-429, https://doi. org/10.2307/2167281.

Dorrien, G. (2004): Imperial Designs. Neoconservatism and the New Pax Americana. Routledge, New York.

Dunn, Ch. W. and Woodard, D. J. (1996): The Conservative Tradition in America. Rowman and Littlefield, Lanham.

Goldwater, B. (2010): The Conscience of a Conservative. Bottom of the Hill Publishing.

Haddigan, L. (2010): How Anticommunism „Cemented" the American Conservative Movement in a Liberal Age of Conformity, 1945-64. Libertarian Papers, Vol. 2, No. 7.

Hart, J. (2005): The Making of the American Conservative Mind. National Review and Its Times. Intercollegiate Studies Institute, Wilmington.

Higham, J. (1959): The Cult of the "American Consensus": Homogenizing Our History, Commentary, February, www.commentarymagazine.com/ articles / the-cult-of-the-american-consensushomogenizing-our-history/.

Hofstadter, R. (1948): The American Political Tradition and the Men Who Made It. A. A. Knopf, New York.

Holmes, S. (1993): The Anatomy of Antiliberalism. Harvard University Press, Cambridge.

Huntington, S. P. (1957): Conservatism as an Ideology. American Political Science Review, June, Vol. 51, No. 2, pp. 454-473, https://doi. org/10.2307/1952202.

Kagan, R. (2002): Power and Weakness. Policy Review, No. 113, pp. 3-28.

Kirk, R. (1993): Ten Conservative Principles. https:// kirkcenter.org/conservatism/ten-conservativeprinciples/.

Kirk, R. (2018): The Six Core Beliefs of Conservatism. https://isi.org/intercollegiate-review/the-sixcore-beliefs-of-conservatism/.
Lee, M. J. (2014): Creating Conservatism. Postwar Words that Made an American Movement. Michigan State University Press.

Lloyd, D. and Davenport, D. (2013): The New Deal and Modern American Conservatism. A Defining Rivalry. Hoover Institution Press, Stanford.

Lovejoy, A. O. (2001): The Great Chain of Being, Harvard University Press, Cambridge.

Maistre, de J. (1994): Considerations on France. Cambridge University Press.

Marx, K. and Engels, F. (1969): Manifesto of the Communist Party. www.marxists.org/archive/ marx/works/1848/communist-manifesto/index.htm.

Meier, H. (2006): Leo Strauss and the Theologico-Political Problem. Cambridge University Press.

Meyer, F. S. (1960): Freedom, Tradition, Conservatism. Modern Age, Vol. 4, pp. 355-363.

Meyer, F. (1962): Why Freedom. National Review, 25 September, reprinted in Meyer, F.: In Defense of Freedom. Liberty Press, 1996, pp. 155-163.

Miles, M. W. (1980): The Odyssey of the American Right. Oxford University Press, New York.

Molnar, T. S. (2011): Bernanos. His Political Thought and Prophecy. Sheed and Ward, New York.

Molnar, T. (1978): Christian Humanism: A Critique of the Secular City and Its Ideology. Franciscan Herald Press, Chicago.

Molnar, T. S. (1987): The Pagan Temptation. W. B. Eerdmans, Grand Rapids.

Molnar, T. (1988): Twin Powers: Politics and the Sacred. Eerdmans, Grand Rapids.

Molnar, T. (1990): Utopia. The Perennial Heresy. University Press of America.

Molnar, T. (1995a): Authority and Its Enemies. Transaction Publisher.

Molnar, T. (1995b): The Case of Georges Bernanos. Modern Age, Vol. 38, No. 1, pp. 61-68.

Nash, G. H. (2006): The Conservative Intellectual Movement in America Since 1945. Intercollegiate Studies Institute.

Nisbet, R. (1980): Conservatives and Libertarians. Uneasy Cousins. Modern Age, Vol. 24, No. 1, pp. 2-8.

Pope Pius X (1907): Pascendi dominici gregis. http:// w2.vatican.va/content/pius-x/en/encyclicals/ documents/hf_p-x_enc_19070908_pascendidominici-gregis.html.

Preece, R. (1980): The Anglo-Saxon Conservative Tradition. Canadian Journal of Political Science / Revue canadienne de science politique, Vol. 


\section{Academic Workshop and Book Reviews}

13, No. 1, pp. 3-32, https://doi.org/10.1017/ S000842390003081X.

Schmitt, C. (1996): The Concept of the Political. University of Chicago Press, Chicago.

Schmitt, C. (2008): Political Theology II. Polity, Cambridge.

Schoenwald, J. (2001): A Time for Choosing. The Rise of Modern American Conservatism. Oxford University Press.

Smant, K. J. (2002): Principles and Heresies. Frank S. Meyer and the Shaping of the American Conservative Movement, ISI Books.
Strauss, L. (1953): Natural Right and History. University of Chicago Press, Chicago.

Tate, A. L. (2005): Conservatism and Southern Intellectuals, 1789-1861. University of Missouri Press.

Trilling, L. (1950): The Liberal Imagination. Viking, New York.

Weber, M. (2004): Politics as Vocation. In: Weber, M.: The Vocation Lectures. Hackett Publishing.

Wilson, F. G. (1941): A Theory of Conservatism. American Political Science Review, Vol. 35, No. 1, pp. 29-43, https://doi.org/10.2307/1947852. 